International Journal of English Literature and Social Sciences
Vol-6, Issue-1; Jan-Feb, 2021
Journal Home Page Available: https://ijeab.com/
Journal DOI: $10.22161 /$ ijels

\title{
Children with Cancer and their Designs: Evaluation of psychological development of children in cancer treatment
}

\author{
Helena Rubia de Santana Botelho ${ }^{1}$, Francisca Morais da Silveira ${ }^{2}$, Marina da Silveira de \\ Melo $^{3}$
}

${ }^{1,3}$ Universidade Ceuma, Brasil
${ }^{2}$ Universidade Federal do Maranhão, Brasil

Received: 01 Nov 2020; Received in revised form: 04 Jan 2021; Accepted: 13 Jan 2021; Available online: 21 Jan 2021 C2021 The Author(s). Published by Infogain Publication. This is an open access article under the CC BY license (https://creativecommons.org/licenses/by/4.0/).

\begin{abstract}
This research aims at understanding the role of childrens drawing in their assessment of their children's psychological development under oncological treatment at the Maranhense Institute of Oncology Aldenora Bello. The paper, classified as field research, with a qualitative and descriptive approach, has been made, initially, through bibliographical inquire. Posteriori it was performed a transversal observational study among children interned at a Reference Hospital in the city of São Luís-MA (Brazil). The data collection was performed through direct observations of the participatory type, also through application of the projective technique of drawing HTP (House-Tree-Person) among the children as well as consulting the hospital's records. As an inclusion criterion, it was adopted: children in a process of oncological treatment between 8 and 12 years age both of male and female sex, with a cancer diagnosis and hospitalized in the institution, loco of the research. As an exclusion criterion, it was adopted: children who weren't in process of hospitalization and those under weakened health conditions without physical conditions to perform a projective technique. The goal of the research was to demonstrate the role of infantile drawing as an instrument to access the emotional reactions and to evaluate the psychological development of the hospitalized child with a cancer diagnosis.
\end{abstract}

Keywords-Psychology of the Development; Child Development; Oncology.

\section{INTRODUCTION}

Childhood cancer represents a leading cause of death in Brazil for children and adolescents aged between 1 to 19 years among all regions, with approximately more than 11,530 new cases of cancer per year. In children, unlike adults, cancer generally affects the cells of the blood system and supporting tissues, with current treatment methods being more efficient and the chances of cure much greater than in adults. It is estimated that around $70 \%$ of children with cancer can be cured if diagnosed early and treated in specialized centers. Most of them will have a good quality of life after adequate treatment (INCA, 2014).

The child in an hospital institution for cancer treatment is faced with a new world, with fantasies in the face of the unknown. Feelings such as insecurity and fear of death arise in the face of becoming ill. Compromised selfimage, cancer pain, invasive and painful treatment, limitations imposed by the disease, behavioral and emotional changes, and the withdrawal of their routines must also be considered, as these are situations that can cause biopsychosocial damage to their. How the child will deal with this new situation will depend on some factors, such as affective and psychic conditions, favorable environmental conditions, previous hospitalization experiences, the stage of development, the evolution of the disease, and the hospital environment (Botelho, 2012).

In this light, Carvalho, cited by Perina (2005), says that it is through playing, drawing, and creating that the child tells their story as the story of their imaginary populated by monsters, cinderella, princes, and bad wolves. 
In this saying and redemption of things, they weaves the threads that lead to the plot of their unconscious, the hidden wisdom that only reveals many times in the symbolism of the drawings and stories they invented. In other words, it is through playing and drawing that the child will express their feelings when he gets sick, revealing to us emotional reactions.

Considering the findings mentioned above,it became essential to carry out research that can assess psychological development during the process of becoming ill, since children undergoing cancer treatment undergo long-term hospitalizations. It was also evident the necessity to translate their needs, that is, to have access to emotional reactions to hospitalization and its implications,through drawings and projections produced by them, and thuselaborate proposals of interest in public health.

In this study, the HTP projective technique was used to understand the role of the children's drawing as an instrument of access to the psychological development of children undergoing cancer treatment, the primary objective of the study. Also having as objectives the description of the benefits of the children's drawing, such as minimizing pain, verbalizing anxieties, fears and fantasies, relating children's drawing, a playful activity, as part of child's development and accompanying the experience of falling ill and the hospitalization in the development of the child with cancer.

Regarding the use of drawings as a projective technique, the creator of HTP, John N. Buck (1948) realized through his clinical experience that the theme "House-TreePerson" involves concepts that encourage more frank and open verbalizations than other topics. It was also discovered that, although houses, trees, and people can be designed in almost an infinite variety of ways, a quantitative and quality assessment system can be designed to extract useful information regarding the level of the subject's intellectual and emotional function (Retondo, 2000).

This work is composed of topics. The first presents the methodological path developed in the research fieldand the authors of reference in the use of the HTP projective technique. Followed by results and confrontation with theory, discussion and final considerations.

\section{METHODOLOGY}

\subsection{Research Location}

The institutions selected for the research were the hospital and a supporting facility named Casa de Apoio Criança Feliz, from the Maranhense Institute of Oncology Aldenora Bello, in the city of São Luís, a reference center in the State of Maranhão in the diagnosis, prevention, and treatment of cancer. It is a non-profit philanthropic institution specializing in the treatment of various cancers, including childhood cancer. The research took place from January 2014 to June 2015.

The institution has a team of specialists in the most diverse areas of health, such as Gynecology, Medical Clinic, Dermatology, Pediatrics, Psychology, Surgeon, Oncology, Physiotherapy, Occupational Therapy, Nutritionist, Speech Therapy, and Radiology focused on the assistance of patients and relatives.

\subsection{Subjects}

In this research, it was chosen sampling by type or intentional, which, according to Gil (1999, p. 104), means selecting a subgroup of the population that, based on the available information can be considered representative of the entire population.

The sample space was comprised of children undergoing treatment, aged between 8 and 12 years old, male and female, diagnosed with cancer, and admitted to the institution or the support home. Usually, the hospital serves 80 children a year on average. They represented typical cases according to the criteria and objectives of the study for the universe of research. Meeting the inclusion and exclusion criteria, the total number of participants was eight children.

According to Alvarenga (2012), sampling is not essential in qualitative studies. It is because one does not seek to generalize the results to the population. The author also states that in-depth studies are carried out, even with few cases presenting the characteristics.

\subsection{Procedures}

The procedures were carried out after approval by the Research Committee, submitted through the Brazil platform, in compliance with resolution 466/12 and its complementaries from the National Health Council (CNS / MS). With CAAE number 39894114.8.0000.5084, approval protocol, and with the consent of the parents or guardians of the research subjects, ICF and with the signature of the subjects themselves, a term of consent. As a way of guaranteeing the anonymity of the participating subjects, they will be referred by P1, P2, P3, and P4.

The procedures started with consultations to the children's medical records and participatory observations during psychological care. Alvarenga (2012) states that participant observation is characteristic of qualitative research. This technique favors the observer to participate in activities with the group under investigation. The observer becomes part of the group. The design of the investigation always remains flexible during the study Generally, the observer begins to investigate without specific hypotheses or prejudices, exploring and observing 
the phenomena as they emerge in the study environment. Try to ask questions that allow the people involved to speak what they think and feel. To facilitate this opening, it is necessary to establish rapport, that is, a cordial relationship, to acquire the necessary trust, enabling the person to manifest freely in their knowledge and feelings regarding the phenomenon of study.

In the next stage, the projective technique was applied to children, HTP. The application took place individually and occurred in the playroom. In this phase of application of the technique, the child was asked to perform the achromatic drawings of the technique, the house, the tree, and a person. The drawings were made freehand. In the second phase, a post-design survey was carried out. The survey questions are related to the individual's associations with the design. In the next phase, the research subjects made the drawings of the technique, chromatic drawings with the use of crayons. The last phase of the technique took place through additional questions to the colored drawing.

For Alvarenga (2012), subjective tests are used in the field of psychology and should be used by specialists to extract qualitative data of relevance, allowing them to appreciate an individual's psychological or personality characteristics. The data extracted through the tests do not seek to explain the causes or effects, but rather to describe behavior according to the objectives of the study. Its application offers no difficulties, its interpretation requires specialized knowledge and experience.

\section{RESULTS}

This research proceeded with the transcription of medical records consultations, observations, HTP analysis, rereading of the material, and organization of the data. As participatory observations and applications of HTP were happening, they were being transcribed.

The classification of data allowed the construction of responses relating to the theoretical framework addressed. The interpretation of the HTP projective technique drawings was made using the criteria of Buck (2009) and Retondo (2000). 46 drawings were interpreted by a total of 8 subjects participating in the research. 6 to 7 drawings are made for each child. As a part of the research, 20 projections of 4 participants are presented.

The investigation of children's drawing in the evaluation of the psychological development of children undergoing cancer treatment allowed us to verify that children's drawing can be used as an instrument in the evaluation of psychological development of childrens hospitalized under cancer treatment, and of access to their emotional reactions.

This finding can be seen in the features shown in the subjects' projections. All subjects projected fantasy and poor orientation towards reality, indicating fantasy as an escape from a stressful environment, which causes pain and limitations. The data referred to above confirm that the objective of monitoring the experience of falling ill and hospitalization in the psychological development of children with neoplasia was achieved, since the proposed investigation of using children's drawings, that is, the HTP technique, enabled the expression of their experiences in this context. In the same way, the reports of each child express their experiences with becoming ill and hospitalization, allowing the researcher to follow up.

It was also found that despite the expressions mentioned above, children with cancer explained liveliness during play activities, during play, whether individually or in a group, that is, the benefits of drawing, such as verbalization of feelings, diverting the focus from the pain by the pleasure of drawing, playing. Data confirmed in the projections made by them. When answering the survey after the drawing, they reported that the trees were fruitful and very alive, without any injuries, due to their care for the tree. According to Buck (2009, p. 41) "a well-adjusted person sees the house occupied by a living being and sees the tree and the person alive". This information ratifies theories of child development, where they ensure that the hospital context is a stressful environment which requires therapeutic procedures that cause pain, fragility, and limitations, but it is also an environment that has life in development. In this way, playing as a universal activity for children cannot be interrupted during hospitalization, not playing is to abruptly interrupt the development of this being.

In the projections of the research subjects, the use of colors was used critically and consistent with reality, even though irrelevant details were observed in some of the projections, and the use of more colors than the projections made by adults. These data explain that despite being in a stressful environment, feeling environmental pressure as evidenced in the drawings above, children demonstrate adjustment to the environment and maintenance of the integrity of the ego. In this state of adjustment, it is clear that children hospitalized for cancer treatment are looking for resources to cope with the situation.

It is worth mentioning that the elaboration of the conflicting situation, of environmental pressure, already shows evidence of the individual's development, since playfully dealing with reality can favor the expression 
of psychological contents surrounding the sick person. Expressing their fear, insecurity, anguish, in short, their feelings in the face of reality favors the maintenance and prevention of physical and emotional integrity. Reaffirming the above mentioned, Chiattone speaks:

...despite the free aspect of the activity, children do not play for playing, as throughout the period we try to talk, guide and support them in the best possible way. The toy itself shows us the path chosen by the child and by which we must enter and work with the existing contents. (Chiattone apud Camon, 2003, p. 72).

\section{Patient 1}

Analyzing the design of the P1 house in figures 1 and 2, we conclude that there is a critical capacity, conflict, anxiety, depression, inadequacy, insecurity, regression, rejection, and need for support. Another detail is the transparency on the walls of the house, suggesting a poor orientation towards reality, understandable data for those who are in a stressful environment, the hospital environment. There is also a defensive attitude, introversion, environmental pressures, and change in psychological state, that is, coping with falling ill, a valid state for those in such a situation.

In the details irrelevant to the house, P1 draws clouds, birds (swallows), reaffirming the aspects mentioned above. Another interesting item in the projections of $\mathrm{P} 1$, in the achromatic and chromatic house, in the tree (figures 3 and 4 ) and the person (figures 5 and 6), is the radiant sun on the left side of the leaf, symbolizing the figure of greatest positive emotional valence, your mother. The relationship based on affection between mother and daughter is evidenced in other projections in the survey, after the drawings, and during the observations.

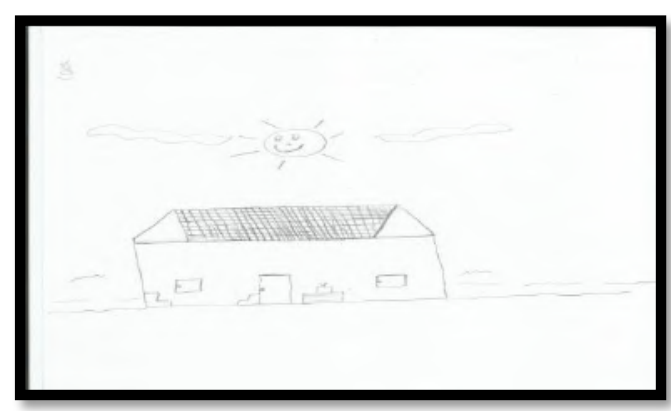

Fig.1: House.

Source: Botelho, H. R de Santana (2016)

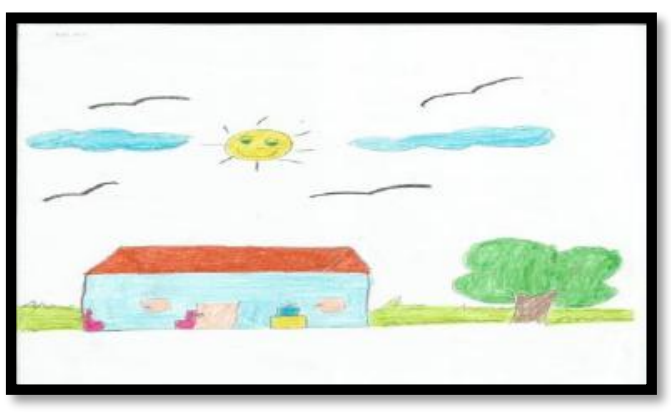

Fig.2: Colorful house.

Source: Botelho, H. R de Santana (2016)

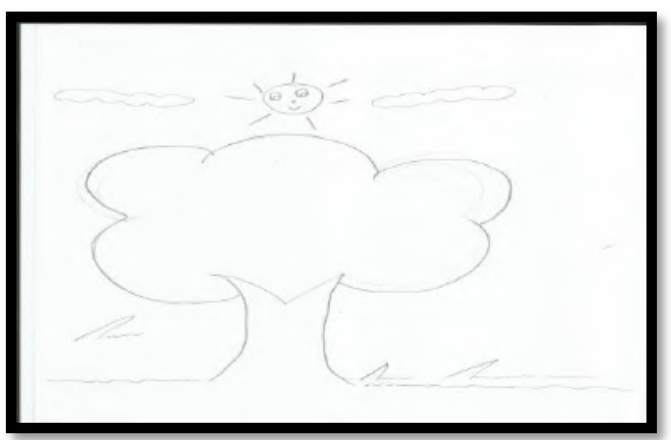

Fig.3: Tree.

Source Botelho, H. R de Santana (2016)

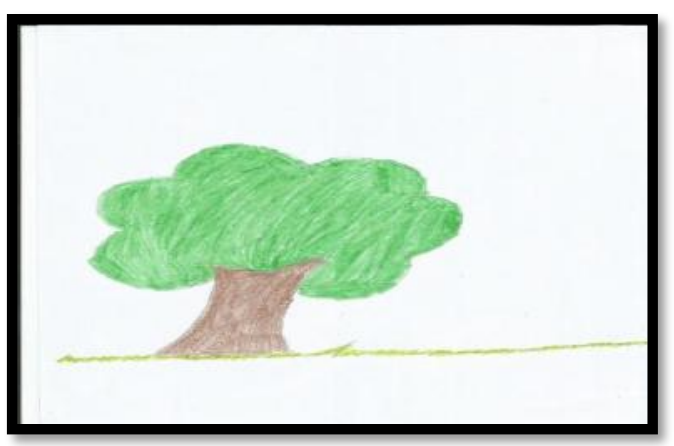

Fig.4: Colored tree.

Source Botelho, H. R de Santana (2016)

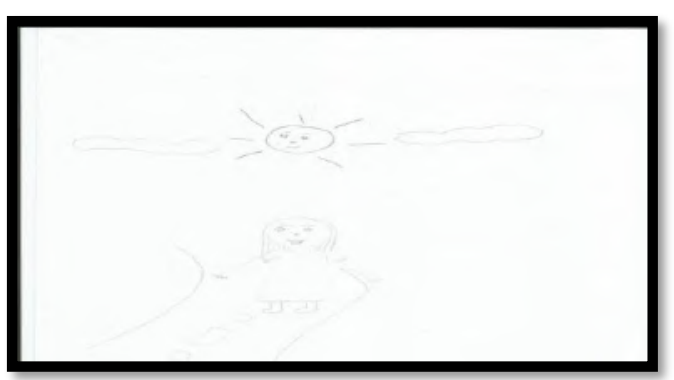

Fig.5: Person

Source: Botelho, H. R de Santana (2016) 


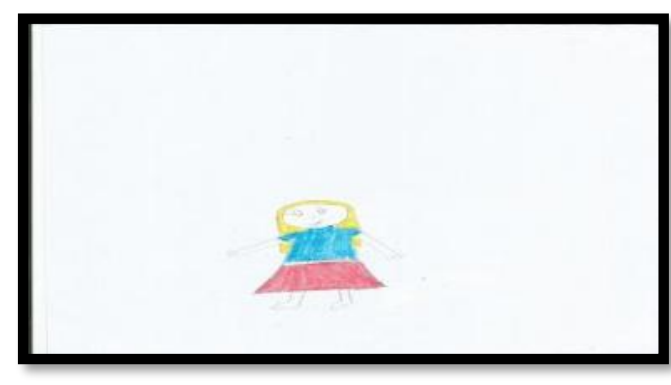

Fig.6: Colored person.

Source: Botelho, H. R de Santana (2016)

In the post-design survey, $\mathrm{P} 1$ reports that the planned house is the one she would like to build to live with her brothers and mother, since her father lives away from the family. The house will be made of bricks and becolorful. Andit was inspired by the neighbor's house, which P1 finds very beautiful. She also reports that if the house were a person, it would be her mother, reaffirming the figure of greatest valence for her. She also expresses her nostalgia for the brothers, when she says that when designing the house, she remembered the brothers who stayed inside and that she wants to see them soon.

Continuing the investigation after the drawing, this time consideringthe drawing of the tree, the examinee refers to it as a living, strong and green mango tree. It was planted alone in a garden, it appears to be 30 years old, starting to bear fruit, with dead leaves, due to the sun and heat. According to P1, the tree looks like a woman, its mother, because she (tree) is happier and bears fruit. The tree brings back memories of her home and brothers, also of herself playing with his friends in the shade that comes from this canopy. She says that the tree is not hurt and that she would never let anyone hurt it. In this survey, the expression of the figure with the greatest positive valence for P1, the mother, is again observed.

In the projection of the tree (figures 3 and 4), there are traces of feelings of tension, compensation, restrictive environment, fragility, dependence, regression, withdrawal, concern for oneself, inadequacy, need for security, anxiety, fantasy, and fixation in the past. These last two traits may have been caused due to the stressful environment, the hospital'scontext, and its painful therapeutic measures, generating fantasy as an escape from a painful reality and the fixation in the past, a setback to health, to family members' companies, to their refuge, the family environment, as she mentioned in the post-design survey, that is, the general well-being.

In the person's inquiry, P1 reports that the drawing is of a 7-year-old girl, her neighbor. When drawing the girl, she thought of her friend, and that she would be going to her house, as it was their habit to always play together. Her friend was very happysmiling, since she loved to play with her. The neighbor reminds her of her cousin, and her sister, who often get together with friends to have fun, expressing here the longing for loved ones. When asking P1 if someone had hurt this person, she replies: "her mother patted her".

In the drawing of $\mathrm{P} 1$, in the person (figures 5 and 6) there is a feeling of insecurity, discontent, regression, fixation on the past, and concern for oneself. Traces are already evidenced in other projections and legitimate due to the situation in which she finds herself. There is also a feeling of rejection, anxiety, need for security, hesitation, fear anda weak ego. In irrelevant details, P1 draws the cloud and the sun, symbolizing environmental pressure, and the sun, according to her account, would be very happy.

\section{Patient 2}

In the figures below are projections of P2, a 12year-old male patient, diagnosed with acute lymphocytic leukemia, 6 months in treatment at the institution, induction of leukemia. He lives with his mother and a younger sister. Son and mother maintain a relationship based on affection and complicity, an aspect observed during the research. The mother accompanies the child in the treatment of cancer. The companion is extremely important for the child and the health team since they can collaborate with the team's procedures and favor the link between the patient and the health team.

P2 is a shy and withdrawn child, he is always beside his mother as if he were asking for her protection and constant presence. However, it interacts well with other patients and with the healthcare team. Participates in the sector's activities, such asplaying activities carried out in the toy library (directed and free activities), extra-hospital tours such as cinema, and theaters, the institution's cultural program. In his report, there is a lack of school and colleagues, a routine interrupted after the diagnosis of ALL, and with the start of treatment outside the home.

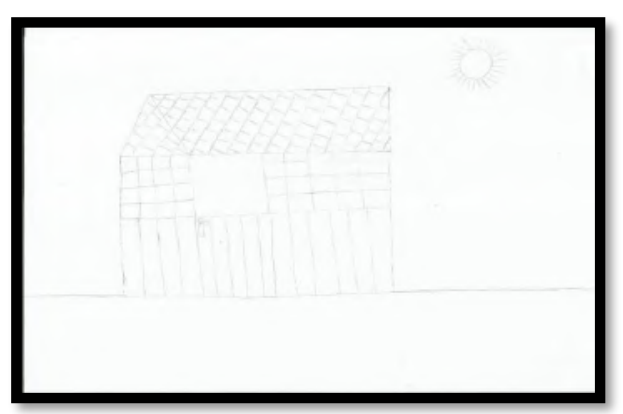

Fig.7: House.

Source: Botelho, H. R de Santana (2016) 


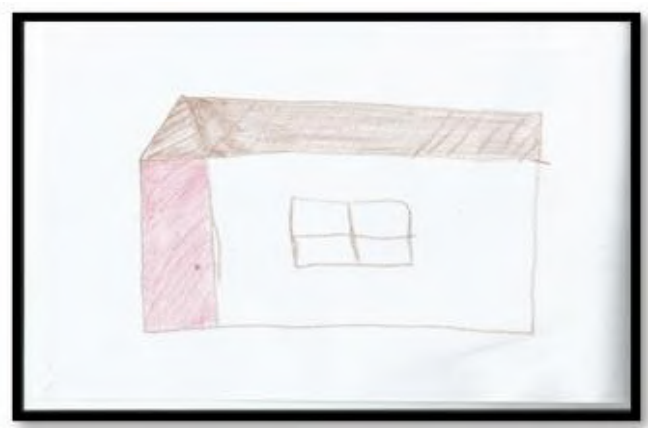

Fig.8: Colorful house.

Source: Botelho, H. R de Santana (2016)

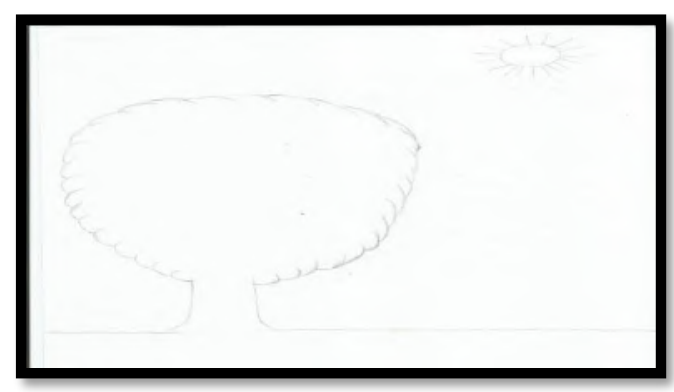

Fig.9: Tree.

Source: Botelho, H. R de Santana (2016)

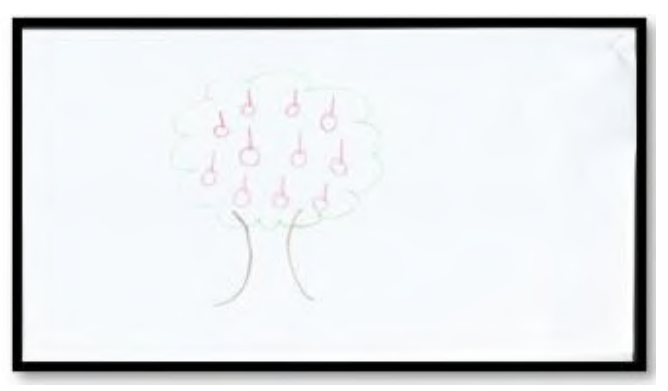

Fig.10: Colored tree.

Source: Botelho, H. R de Santana (2016)

In the drawings of $\mathrm{P} 2$ 's house (figures 7 and 8), there are traces of tension, compensation, restrictive environment, withdrawal, regression, concern for oneself, fixation on the past, impulsivity, need for security, anxiety, dependence, defensive attitude, introversion, and refuge in fantasy. Understandable traits, due to his condition. Escape and denial are resources that the patient is looking for to cope with becoming ill. The sun is also observed on the right side of the leaf, suggesting the child's perception of the father. Detail evidenced in other projections of the examinee.

In the subsequent survey of the house, P2 says that this is his house. He reports that he made the drawing just like it, that is, he was thinking about his residence when designing the house. And he would like his whole family to live in the house toobecause he likes everyone together. The house reminds him of his grandmother, his sister, and his entire family. In this investigation, the examiner may be expressing the longing for his family, grandmother, and sister, the difficulty of staying so long, months or years in treatment, away from family members and loved ones. However, P2 can still see joy, since, when asking if the house is a happy or friendly type, he says yes, and adds in the verbalization that everyone together, the family, brings happiness. He also notes that the people he lives with are happy. According to him, the drawing time is sunny and hot, high temperature, and windy slowly. If the house were someone, it would be your maternal grandmother, since this is a very special person. For him, the house needs joy, even more, a joy that would come with everyone together.

In the tree projection ( 9 and 10), P2 illustrates feelings of uncertainty, conflicts, anxiety, self-criticism, restrictive environment, tension, compensation, withdrawal, impulsivity, dependence, and concern for oneself. Feelings are already evidenced in other projections.

The research subject demonstrates concretism, inadequacy, insecurity, need for security, weak ego, hesitation, fear, and fantasies. Justifiable feelings due to coping with falling ill.

In the investigation of the tree, he sees it as a mango tree, finding himself alive, planted in his backyard, he is around 50 years old, bears many fruits, mangoes. It looks like a womansince it bears fruit (as if the woman bears fruit). She is not alone; she is in groups. For P2 the weather is cloudy, there is a strong wind and blowing to the left. The tree reminds him of his tender childhood and that of his family, taking the fruit from the mango tree. Due to the care he has with the house, it is strong, it is watered by him and whenever he can, he puts water on his roots, as statedby the participant. If the tree were a person, it would be your maternal grandmother. The responses of the tree's survey reassure that of the house, identification that the participant has with his grandmother, the age of the tree, the comparison with a woman, bearing fruit or giving birth, having children, among others.

\section{Patient 3}

In the P3 projections of 11 years old, female, diagnosed with ALL leukemia, and in treatment for eight months. Coming from the interior of the State, and having as a companion his father, an unusual fact in the institution, being the maternal figure the most common in the care of hospitalized children. P3 is the eldest daughter of the couple, having two more sisters. Concerning the sisters, she expresses affection, longing, and desire to see them soon. A common situation in patients coming from the countryside, 
the distancing from the family, from friends, in short, from their routines.

$\mathrm{P} 3$ is receptive to psychological care, participatory in play activities, good interaction with other patients, and a good bond with the health team. She is a child with easy, sensitive laughter and appears to have a life impulse, which according to Freud, quoted by Laplanche and Pontalis (2001, p. 414), is:

Pulse of life. Freud opposes in his latest theory, the death drives. The life drives, also referred to by the term "EROS", include not only the sexual drives themselves, but also the drives for selfpreservation.

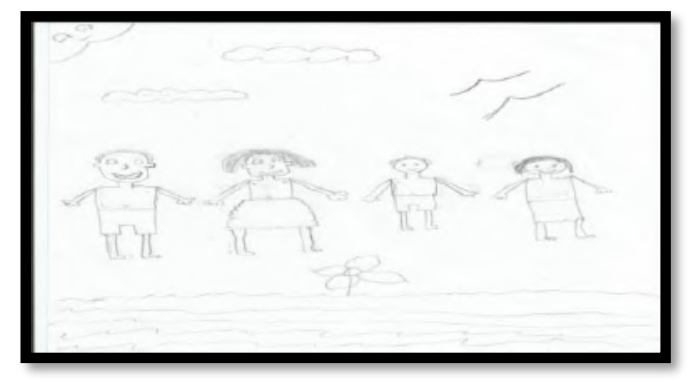

Fig. 11: Family.

Source: Botelho, H. R de Santana (2016)

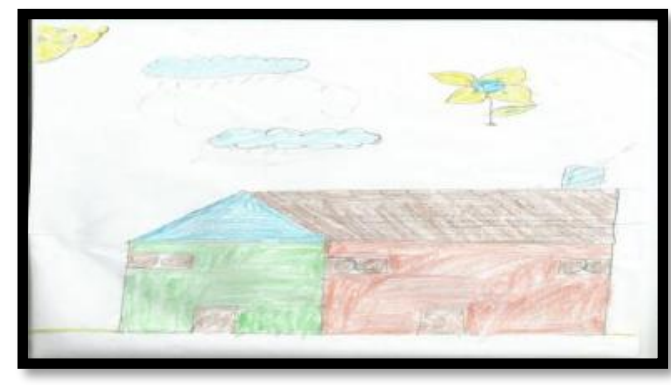

Fig.12: Colorful house.

Source: Botelho, H. R de Santana (2016)

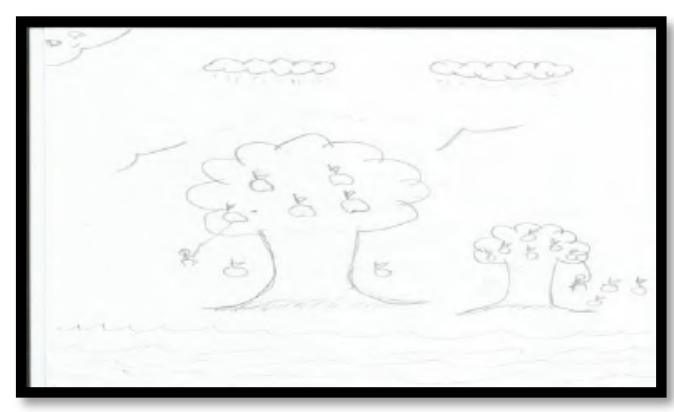

Fig.13: Tree.

Source: Botelho, H. R de Santana (2016)

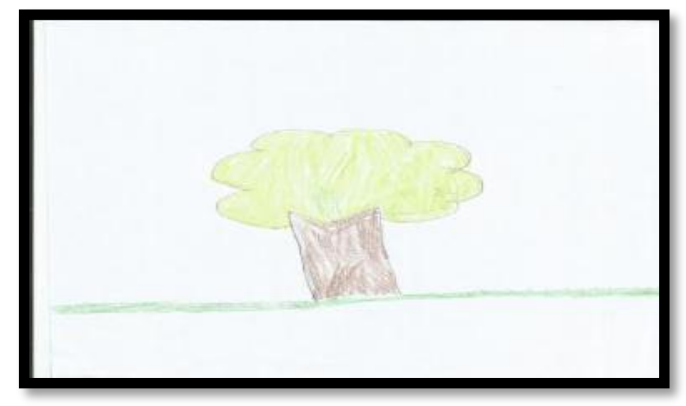

Fig.14: Colored tree.

Source: Botelho, H. R de Santana (2016)

When drawing, the child seems to project a desire or, perhaps, an attempt to possess an object; if, in reality, you don't get it, at least you have an image of it. Starting from this idea and examining the projections of $\mathrm{P} 3$, there is a consensus between the statement of the aforementioned author and the projection of a desire. In the drawings by P3, the house and the family have a flower, which can symbolize the search for affection, a desire to receive affection (Di Leo, 1985).

Another common detail in $\mathrm{P} 3$ projections is the presence of clouds in almost all productions. According to the authors mentioned above, the presence of clouds suggests pressure from the environment on the subject, refers to an adequate perception exerted by the change, such as hospitalization, therapeutic procedures, distance from friends and family, physical limitations imposed by the disease, among others.

In the drawing of the house of P3 (figure 12) there are traces of uncertainty, conflicts, indecision, tension, the anticipation of the future, concretism, depression, insecurity, opposition, rejection, need for security, anxiety, regression, reserve, defensive attitude, withdrawal, and evasion. However, there is also stability, control, and the ability to postpone gratification. The features observed in the projections are comprehensive and acceptable in the condition she is in, facing the illness and its implications. It projects a radiant sun on the left side of the drawing. According to Bédard (1998, p. 45), the sun in this position represents:

The past, and also the bond with the mother, can represent the influence of an independent mother who acts without taking too much into consideration. When their rays are too large, they are showing us a mother who may be too enveloping. 
The author further states that the stronger the rays are, the more danger there is that the mother is one of those who want to impose her will and control everything.In the case mentioned above, P3 expressed in the drawn sun, the most authoritative figure, with positive emotional valence. Data confirmed by the father, his companion, and in the post-design survey.

In the verbalizations expressed in the survey after the design of the house, $\mathrm{P} 3$ states that he would like this to be his residence, as it is beautiful and colorful. The house has only one floor, it is built of wood and when designing it she was thinking about the sisters, the mother, and the grandmother. It expresses the longing she feels for family members who stayed in the country. If P3 could choose a room in the house, she would choose the room that is closest to the living room, so she could follow all the movement within the house. When verbalizing this desire, the examinee compares the house designed with the support house, which is hosted. It is perceived in the desire, the longing for the family routine, and the desire to return to its origins. In this, P3 is accommodated in the first bedroom, and according to her story, she follows the whole movement of the house, because everything starts in the room.

Still in the survey, $\mathrm{P} 3$ reports that she would like the researcher to live with her in the house since she likes its company. To her, the house looks happy, because the residents are happy, and that most of the houses she knows are happy. P3 attributes this happiness to having a home. For her, the house needs tiles and a better floor. This way the house would be much more beautiful.

According to the participant, the weather in the drawing is rainy, cold, and it is winter season, the preferred season forher. As the investigation continues, P3 is asked if the house were a person, who would it be? She replies that it would be the mother and the grandmother, indicating the identification she has with both.

In the projections of the trees (figures 13 and 14), there are achromatic and chromatic traces already found in the projection of the house, such asuncertainty, conflict, indecision, anxiety, self-criticism, environmental pressures, inadequacy, among others. Besides, one could also identify dependency, fantasy, immaturity, rejection, tension, energy, and organicity. The examinee projects two trees in the achromatic design suggesting affective lack, and need for support.

In their verbalizations, expressed in the survey, P3 describes the tree as fruitful, an apple tree, aged 50, planted in her yard, strong, healthy, bears good fruit and is very much alive. The reason that describes the tree as alive would be the abundance of fruit. It also classifies the tree as a woman, explaining that the male tree does not bear fruit and only needs water to stay alive. If this tree were a person, she would be facing, and it reminds her of his mother and grandmother. The latter, because she has many plants, and the former because of the coconuts plantation she owns. Again, P3 expresses the identification and the positive emotional valence that the maternal figure represents for her.

In the same survey, that of the tree, when asking P3 if this was a person instead of any object, who could it be. She replies that it would be her little sister because he loves to climb trees. The participant repeats that weather in the drawing of the tree is the same as in the house, rainy and cold.

P3 expresses the desire to draw the family (figure 11) instead of drawing the person and was left at ease for his chosen production. According to her account, this family is her, her father, her mother, younger sister, and the one examining her. When drawing everyone front-facing, standing, and erect.The projection suggests a structured, adapted family that faces problems head-on. P3 draws family members with proximity between the figures, indicating a feeling of interaction, solidarity, and pertinence. These feelings were confirmed through other sources, that is the report of the father and the child herself. The mother is projected as the largest figure in the group, the dominant parent, regardless of her actual physical size. Regarding the actual size, the examiner and her companion report that the mother is of short physical stature, much smaller than the father, who is of average stature. This projection symbolizes greater importance and valorization of the mother, a figure that gives more attention or wishes that he be the ideal figure, that is, the figure with the greatest positive or negative valence. In the projection in question, the positive valence. Symbolization was already evidenced inother projections and surveys after the P3'sdrawing. The mother's figure was the first to be drawn, reaffirming the above features. Another detail of P3's family is the omission of her middle sister, she only draws the younger sister. The brothers' omission in the projection suggests jealousy of the brothers.

In the drawing of the P3's family, it projects clouds, revealing environmental pressure to us, a detail seen in other projections.

P3 draws some family members with transparent details, such as the breasts and the navel. According to Bédard, transparency can tell us two things:

The first one would show us an intelligent and intuitive child, able to perceive the thoughts of others or to predict the evolution of a determined situation. I 
mean, a child who sees beyond appearances. The second, less favorable, a child inclined to lie and used to camouflage his thoughts would reveal to us. In addition, she is fully aware of her behavior, which makes her feel certain guilt (Bédard, 1998, p. 28).

Regarding the child participating in the research, and the author's statement, the projective technique applied and the participatory observations made in the hospital context, the first indication is more consistent with the behavior of $\mathrm{P} 3$, since she is able to perceive the evolution of her situation. P3 was shown to be aware of her situation, that of falling ill, and the context that is inserted, the hospital's context.

\section{Patient 4}

P4 is a 12-year-old female child diagnosed with ovarian cancer, undergoing cancer treatment for nine months. He has six brothers and a nephew from his 16-yearold sister. When talking about his nephew, his eyes shine. P4 came from the country in search of treatment for childhood cancer, havingher mother as a companion. She is a withdrawn child, but receptive to interpersonal interaction with the team and with other children.

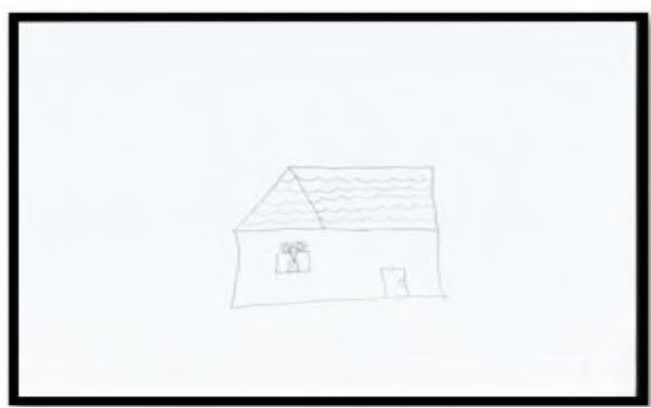

Fig.15: House.

Source: Botelho, H. R de Santana (2016)

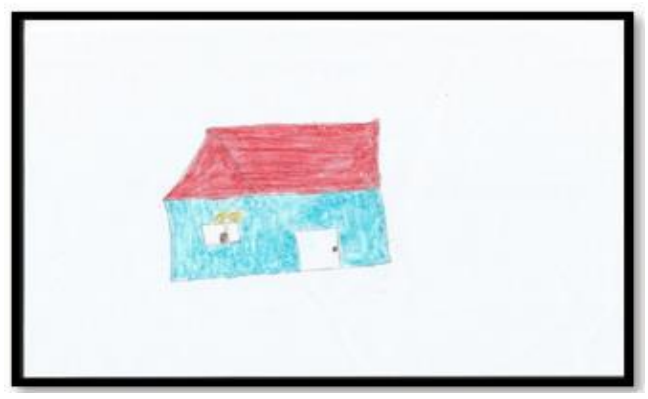

Fig.16: Colorful house

Source: Botelho, H. R de Santana (2016)

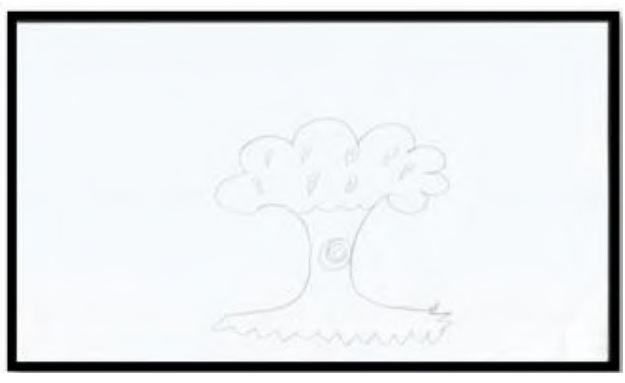

Fig. 17: Tree.

Source: Botelho, H. R de Santana (2016)

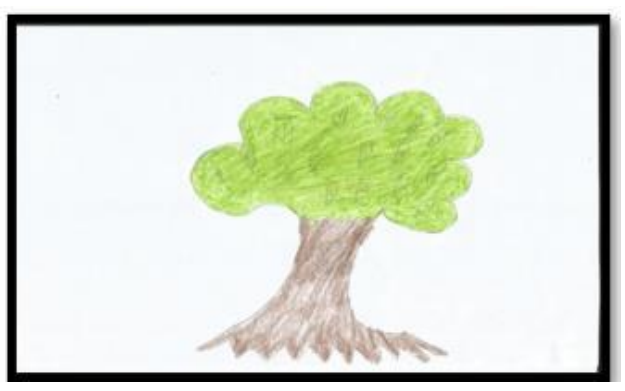

Fig.18: Colored tree.

Source: Botelho, H. R de Santana (2016)

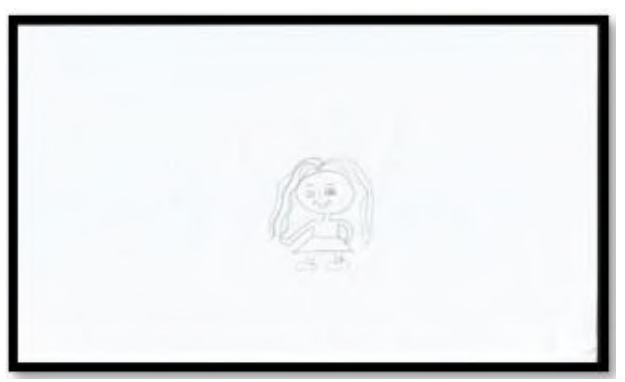

Fig. 19: Person.

Source: Botelho, H. R de Santana (2016)

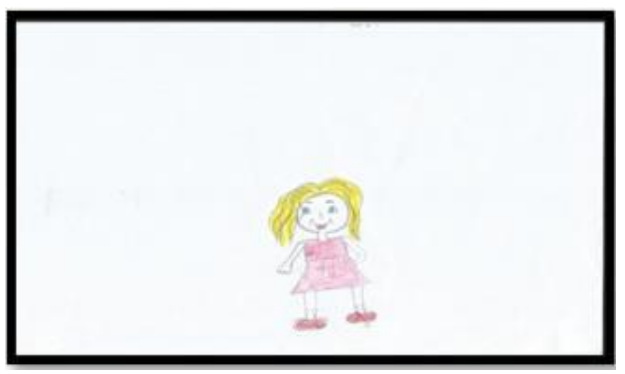

Fig.20: Colorful person.

Source: Botelho, H. R de Santana (2016)

Analyzing the $\mathrm{P} 4$ projections above, there are traces of insecurity, withdrawal, discontent, regression, anxiety, concern for the environment, the anticipation of the 
future, concretism, inadequacy, depression, ability to postpone gratification, poor orientation to reality, defensive attitude, poor ego control, hesitation, fear, and weak ego. Moderate anxiety is also observed in the projection of the house, as well as organicity, grandeur, rigidity, tension, as well as the aforementioned traits.

In the subsequent survey in the house (figures 15 and 16), the participant states that the house has only one floor, it is made of bricks, it belongs to no one, but when drawing it, she thought of her house and would like it to be her own, although not aware of the reason for the desire. She would like her family to live in the house of her projection, so it would maintain the family's union. P4 says it is a happy home since there is unity between family members. However, not all houses are happy, some lack unity. It is possible to observe in the survey the expression of the importance that the family's union has for the examinee. Through projections, onehas access to unconscious contents. Still in the investigation, she reports that the house needs renovation, and the projection'sweather of the house was on a hot summer morning, but the weather of her preference is rainy. If the house were an object or a person, she says it would be her mother, thus expressing identification with her mother.

In the tree's projection (figures 17 and 18), it is possible to observe traces of uncertainty, conflict, selfcriticism, feeling of restrictive environment, tension, compensation, fantasy, opposition, hostility, dependence, immaturity, environmental pressures, rejection, failure in the overcoming mechanism, but also energy, alongside some of the previously observed traits.P4 expressed in the tree survey that this is a mango tree, it is in the backyard of his house, it is approximately fifteen years old, has leaves and fruits, thus showing that it is alive. According to her, if the tree were a person or an object, it would be a man, the younger brother. When asked what gives her such an impression, she says it is the color of the tree that makes her think of her brother. For P4 the tree is in a group. The projection'sweather is the same as for the house. The tree reminds her of nature, the backyard of her house.It is healthy, because it is green, bears fruits, and it is strongsince even with the strong wind, it does not fall. She needs care, nature needs care notto die, according to P4. In these verbalizations, the examiner may be expressing his feelings about becoming ill, even though he is ill, facing the implications of the disease, she remains strong, without falling, like the tree of his projection, that needs care not to die.

After drawing the person (19 and 20), P4 replies that he is a girl of approximately six years old, her younger sister. It is because, when drawing, she was thinking about her sister. For her, the sister is happy, thus beingan expression of happiness in the projection. According to $\mathrm{P} 4$, not all people are happy like their sister. According to her, the drawn person is smiling, making her feel happy. She realizes that the drawing reminds her of herself, when she was younger, and was at the age of her sister, and reminds her of her beloved nephew. The person is dressed in a skirt and blouse. She also reports that she likes this sister very much, as she is very affectionate, and would like to be like her. When asked what this person needs, P4 responds: love and care, as a child needs more love than adults. According to $\mathrm{P} 4$, the girl in the projection has already been hurt by an adult, "hit" and blamed because she did the wrong thing. The weather in this projection is the same as the othersmentioned earlier. At the end of the survey, when asked if the projection were a person or object, what it would be,she replies that it would be her.

Observing that she is talking about herself in the investigation, that is, she wanted to be six years old again, to regress to a stage before falling ill, to escape reality, from the hostile environment and with so many limitations imposed by the disease. It is also observed that theprojective technique allowed her access to her anguish and fears, as mentioned above.

\section{DISCUSSION}

In the projections carried out during the research, the expression of the need for support and the insecurity generated by falling ill, by hospitalization, are also evident. Understandable traits for those who had their routine interrupted, invaded by the implications of falling ill. This information corroborates the purposes of HTP, namely, to reveal specific aspects of the environment in which the child is inserted.

In one of the research's findings in the research subjects' projections, the fixation on the past may suggest a regression to the health, to the family's environment, to the school routine, to friends.In short, to the company of loved ones. The difficulty in carrying out cancer treatment away from home, since most patients come from the country, and the months or sometimes the years apart from family members are reported in the survey after the drawing. All of them expressed being homesickand missing their routines. In their projections, they portrayed grandparents, cousins, friends, their houses with their gardens, and the memories of a healthy childhood full of games.

The emotional expressions mentioned above confirm the theory of the creator of the projective technique, HTP: 
For Buck, highly emotional individuals use many colors: children use more colors than adults. This is in line with the belief that emotional responses precede intellectual responses in the development process. Regressed individuals use colors more freely and with less criticism than non-regressed individuals (Buck, 2009, p. 41).

Corroborating with the author's statement above, one observes that the emotional reactions expressed during the research preceded the intellectual ones, since some details of the projections did not match the reality, but rather the feelings in the face of falling ill and hospitalization. Regarding emotional expressions, it is possible to note that elaboration of conflicts is favored, as well as coping with anguish, and also the psychological development process, since facing conflicting situations is to reinforce the ego, thus developing it.

In the surveys after the drawing, it was possible to see free expressions of feelings, such as homesickness for their personal belongings, the desire for healing, and identification with figures of greater positive value, such as mothers and grandparents. It was also observed impotence in the face of falling ill, the physical limitations that the disease brings, the discomfort caused by hospital routines, by invasive and painful procedures, by the debilitated physiognomy that prevents them from having a normal routine for a child aged 10 to 12 years.

In agreement with the aspects mentioned in the paragraph above, and relating to the hospital environment, Di Leo (2004, p. 44) is quoted, which states:

City kids then draw country houses, instead of the buildings they live in and see constantly. This could also explain why children without a home of their own, living in nursing homes, which they want to be temporary, will draw their yearning for a home, a symbol of the warmth and affection that frustrated them and that only family life can provide.

From the analysis of the projections, and from the surveys after the drawing, it was possible to verify that, despite the suffering due to the disease, hospitalization, and longing for family members, friends, and the school context, that is, elements that can threaten the psychic integrity, or cause sequels in the development of these children, they have internal and external resources.

These resources can be directlylinked to the alternation of the position of coping with grief and struggle, and to the expressions of emotional reactions through children's drawing, playfulness, HTP projective technique. The latter allows the continuation of the stimulation of psychological development since cancer treatment requires a long hospitalization, and to deprive the child of playing during his stay is to deny their needs, universal needs, playing a fundamental part of the individual's psychological development.

In addition to stimulating children's psychological development, the HTP projective technique is commonly used to assess the personality, the psychological dynamics of the individual. The elements of the technique, such as the house, the tree, the person, and finally the family, introduced by some experts in projective technique, are known and portrayed by children of all cultures, since they are universal elements (RETONDO, 2000). Some experts refer to children's drawings as representations and not reproductions. For others, drawing as well as playing in general, fulfills the needs of children in hospitalization, understanding these as reasons that impel the child to action. And it is exactly these needs that make the child move forward in his development.

Considering the aspects mentioned above, Di Leo (2004, p. 45) says that:

The selection of the three elements is based on their supposed symbolic meaning. The house is interpreted as representing the development of the subject, the tree its growth and the person an expression of the integrity of the personality. Apart from considerations about the validity of the projective instrument, it is noteworthy that the three topics are often and spontaneously drawn by children.

Given the explanations and discussion of the results, it appears that the technique used to analyze the psychological dynamics of the research individual reached the proposed objective of the research since the HTP, when combined with other instruments of scientific investigation, can lead to conflicts and general interests of individuals, as well as specific aspects of the environment that he considers problematic, according to Buck (2009). That is the hospital context, the disease and its implications, such as prolonged hospitalization.

\section{FINAL CONSIDERATIONS}

Based on the theories presented in this article,ondrawing in the assessment of the psychological development of children undergoing cancer treatment, it was necessary to 
reflect on projections as an instrument of child evaluation. Throughout the discussion, the importance of the expression of the emotions was emphasized, as well as the access to the unconscious contents of children with malignant neoplasms, and the role of playfulness during hospitalization, factors favorable to the child's psychological development.

The analyzed data allow us to conclude that the way in which the child will deal with this new situation will depend on some factors, such as affective and psychic conditions, favorable environmental conditions, previous hospitalization experiences, the evolution of the disease, the hospital'senvironment, and the stage of development.

All theorists cited in the survey were unanimous in stressing the importance of the surrounding environment, that is, the hospital environment, for the child's development and global health. Such children, who were favored with this environment, tend todevelop resources to deal with their internal and external reality and children who have been deprived of that good enough environment will have a distorted psychological development in some ways. Among the aspects that make up a favorable environment, the referred research theorists cite drawing, painting, playful activities, which, in addition to assessing child development, encourage continuity in psychological development. It is also noteworthy that the children's drawing favors the child, the domain of anguish that afflicts him, which steals most of his psychic energy and, consequently, causes him suffering in the face of becoming ill.

From the arguments and theories previously mentioned in this work, it appears that there is a consensus among theorists, that children's drawing can be used as an assessment tool for psychological functioning, psychic dynamics, and meets the needs of children in coping with the process of illness.

Given these statements, we can consider that the research results are in line with the arguments presented. The children participating in the research gave us a sign of their healthy development, without distortions, by showing the ability to establish links with the health team and other patients, that is, interacting in a healthy way with the surrounding environment.

In conclusion, the findings of this study allow us to reaffirm that we had access to the emotional reactions of the research subjects, children with malignant neoplasms and undergoing cancer treatment, due to the assessment of psychological development. What was confirmed by the results was the elaboration of the conflicting situation, the search for physical and psychological integrity, the expression of the feelings such as environmental pressure, fantasy, insecurity, fear, longing, among others. The expression of emotional reactions, the search for coping resources, that is, the egoic reinforcement, are already showing signs of psychological development. Thus, it can be said that children's drawing acts as a facilitator of expressions of feelings, fantasies, anguish in the face of falling ill, and, consequently, the advancement in psychological development.

\section{REFERENCES}

[1] Gerami-Camon, Valdemar Augusto. (2003). A psicologia no hospital. São Paulo: Pioneira.

[2] Alvarenga, Estelbina Miranda de. (2012). Metodologia da investigação quantitativa e qualitativa. $2^{\mathrm{a}}$. Edição. Versão em português: Cesar Amarilhas, Asunción.

[3] Bédard, Nicole. (1998). Comment interpréter lês dessins de votre enfant. Trad. Maria Lúcia de Carvalho Accacio. Canada. - Les Éditions Quebecor.

[4] Botelho, Helena Rúbia de Santana. (2012). Câncer e laços afetivos: relato de uma experiência. Imperatriz, MA: Ética.

[5] Buck, John N. (2009). HTP: casa-árvore-pessoa, técnica projetiva de desenho: guia de interpretação; tradução Renato Cury Tardivo. 2. ed. São Paulo: Vetor.

[6] Carvalho, M. Margarida M. J. (2003). Introdução à psiconcologia. São Paulo: Ed. Livro Pleno.

[7] Cintra, Elisa Maria de Ulhôa. (2009). Pensar as feridas. In: Coleção memória da psicanálise: Melaine Klein: volume 4/ Graziela Costa Pinto. São Paulo: Duetto Editorial.

[8] DI Leo, Joseph H. (1985). A interpretação do desenho infantil. Trad. de Marlene Neves Strey. Porto Alegre, Artes Médicas.

[9] Gil, Antônio Carlos. (1999). Métodos e técnicas de pesquisa Social. 5 ed. São Paulo, Atlas.

[10] Instituto Nacional Do Câncer. Particularidades do câncer infantil. Disponível em: 〈http://www.inca.gov.br/conteudo_view.asp?id=343>. Acesso em: 11 de Jan, 2014.

[11] Laplanche; Pontalis. (2001). Vocabulário da Psicanálise. 4 ed. São Paulo: Martins Fontes.

[12] PERINA, Elisa. (2005). As dimensões do cuidar em Psicooncologia Pediátrica. São Paulo Ed. Livro Pleno.

[13] Retondo, Maria Florentina N. Godinho. (2000). Manual prático de avaliação do HTP. São Paulo: Casa do Psicólogo.

\section{ANNEX 1- OPINION OF ETHICS COMMITTEE}




\section{CENTRO UNIVERSITÁRIO DO Platoforma MARANHÃO - UNICEUMA}

\section{PARECER CONSUBSTANCIADO DO CEP}

DADOS DO PROJETO DE PESQUISA

Titulo da Pesquisa: A CRIANÇA COM CANCER E SEUS DESENHOS: UMA PROPOSTA DE AVALIAÇÃO DO DESENVOLVIMENTO PSICOLÓGICO DE CRIANÇAS EM TRATAMENTO ONCOLOGICO.

Pesquisador: HELENA RUBIA DE SANTANA BOTELHO

Area Temática:

Versăo: 1

CAAE: 39894114.8 .0000 .5084

Instituição Proponente:

Patrocinador Principal: Financiamento Próprio

DADOS DO PARECER

Número do Parecer: 978.558

Data da Relatoria: 22/12/2014

Apresentaçāo do Projeto:

A pesquisa, classificada como estudo de campo, com abordagem qualitativa e descritiva, acontecerá inicialmente por meio de levantamento bibliográfico, com o objetivo de construir um arcabouço teórico sobre - tema, que direcionará com mais segurança o processo de pesquisa. A posteriori realizar-se-á estudo observacional transversal com crianças internadas em um Hospital de Referência da cidade de Såo Luis MA. A coleta de dados será feita através de observaçóes diretas do tipo sistemáticas, aplicaçăo da técnica projetiva HTP com as crianças e também

consultas nos prontuarios.

Objetivo da Pesquisa:

Investigar o desenho infantil como instrumento de avaliaçấo do desenvolvimento psicológico de crianças em tratamento oncológico.

Avaliação dos Riscos e Beneficios:

Riscos: Riscos mínimos, jả que năo serão realizados procedimentos invasivos. Serão tomados todas as medidas necessárias para preservar 0 anonimato dos participantes.

Beneficios:

Enderę̧o: DOS CASTANHEIROS

Bairro: JARDIM RENASCENCA

UF: MA Municipio: SAOLUIS

CEP: $65.075-120$

Telefone: (98)3214-4265 Fax: (98)3214-4212

E-mail: cep@ceuma.br

\section{ANNEX 1- OPINION OF ETHICS COMMITTEE}




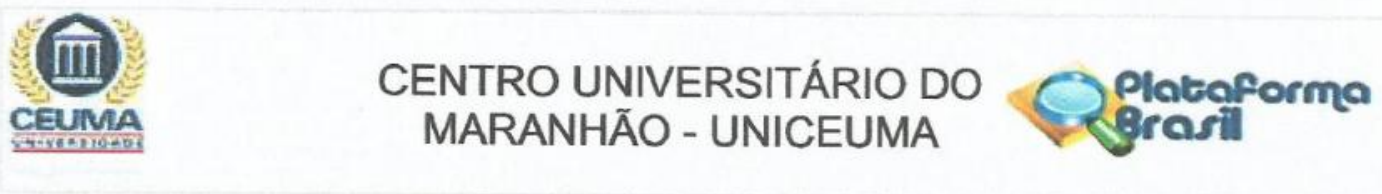

Continuaçăo do Parecer: 978.558

Propor, a partir dos resultados obtidos, a utilização do desenho, durante o tratamento oncológico infantil, como instrumento de acesso às reações

emocionais frente ao adoecer, com objetivo de prevenir impactos consideráveis na saúde global da criança.

\section{Comentários e Consideraçōes sobre a Pesquisa:}

A pesquisa apresenta relevância cientifica e certamente contribuirá para esclarecer aspectos importantes a respeito do tema. A equipe executora apresenta a capacitação necessária para realizar a pesquisa.

Considerações sobre os Termos de apresentação obrigatória:

Todos os documentos obrigatórios foram apresentados e encontram-se corretamente preenchidos.

Recomendações:

Nenhuma

Conclusōes ou Pendências e Lista de Inadequações:

Projeto aprovado

Situação do Parecer:

Aprovado

Necessita Apreciação da CONEP:

Não

Consideraçōes Finais a critério do CEP:

SAO LUIS, 10 de Março de 2015

Assinado por:

Eduardo Durans Figuerêdo

(Coordenador)

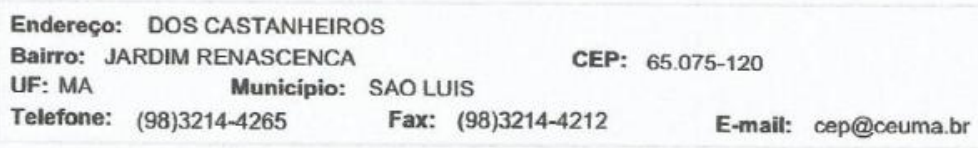

